\section{Strithmetic:}

Academic Journal of Math
Vol. 02, No.01, Mei 2020, Hal.15-34

p-ISSN:2657-0440; e-ISSN:2686-0740

email: arithmetic@iaincurup.ac.id

http://journal.iaincurup.ac.id/index.php/arithmetic

\title{
Penerapan Pembelajaran Realistic Mathematics Education dengan Strategi Means Ends Analysis untuk Meningkatkan Kemampuan Berpikir Kritis
}

\author{
Helen Utarni ${ }^{1}$, Fauzi Mulyatna ${ }^{2}$ \\ ${ }^{1}$ SMK Malaka, ${ }^{1,2}$ Universitas Indraprasta PGRI \\ 1'utarnihelen@gmail.com, ${ }^{2}$ fauzi.mulyatna@unindra.ac.id
}

\begin{tabular}{|c|c|}
\hline Article Info & Abstract \\
\hline $\begin{array}{l}\text { Article history: } \\
\text { Received Feb } 26^{\text {th }}, 2020 \\
\text { Revised April } 20^{\text {th }}, 2020 \\
\text { Accepted May } 22^{\text {th }}, 2020\end{array}$ & $\begin{array}{l}\text { This research is an effort to improve students critical } \\
\text { thinking ability by applying Realistic Mathematics } \\
\text { Education (RME) learning with Means Ends Analysis } \\
\text { (MEA) strategy. The method used in this research is } \\
\text { classroom action research in } 2 \text { cycles. Each cycle passes } \\
\text { through } 4 \text { stages; they are planning, implementation, }\end{array}$ \\
\hline $\begin{array}{l}\text { Keywords: } \\
R M E ; \\
M E A ; \\
\text { Critical Thinking }\end{array}$ & $\begin{array}{l}\text { observation, and reflection. The learning process in } \\
\text { class X IPS-3 for each cycle uses RME approach with } \\
\text { MEA strategy. Students are given an essay test at each } \\
\text { end of the cycle to measure their critical thinking } \\
\text { abilities. Conclusion shows that students, critical } \\
\text { thinking ability increases from } 56 \% \text { (cycle I) to } 84 \% \\
\text { (cycle II) by applying RME approach with MEA } \\
\text { strategy. }\end{array}$ \\
\hline $\begin{array}{l}\text { Kata Kunci: } \\
\text { RME; } \\
\text { MEA; } \\
\text { Berpikir Kritis }\end{array}$ & $\begin{array}{l}\text { Abstrak } \\
\text { Penelitian ini adalah upaya meningkatkan kemampuan } \\
\text { berpikir kritis siswa dengan penerapan pembelajaran } \\
\text { Realistic Mathematics Education (RME) disertai strategi } \\
\text { Means Ends Analysis (MEA). Metode penelitian } \\
\text { digunakan penelitian tindakan kelas dalam } 2 \text { siklus, } \\
\text { untuk setiap siklusnya melalui } 4 \text { tahapan, yaitu: } \\
\text { perencanaan, pelaksanaan, pengamatan, dan refleksi. } \\
\text { Proses pembelajaran di Kelas X IPS-3 tiap siklus } \\
\text { menggunakan pendekatan RME dengan strategi MEA. } \\
\text { Siswa diberikan tes berbentuk uraian pada setiap akhir } \\
\text { siklus untuk mengukur kemampuan berpikir kritis. } \\
\text { Simpulan menunjukkan kemampuan berpikir kritis } \\
\text { meningkat dari } 56 \% \text { (Siklus I) menjadi } 84 \% \text { (Siklus II) } \\
\text { dengan penerapan pendekatan RME dengan strategi } \\
\text { MEA. }\end{array}$ \\
\hline
\end{tabular}




\section{PENDAHULUAN}

Pada kondisi ideal, dalam penelitian-penelitian sebelumnya, melalui eksperimen maupun penelitian tindakan kelas, siswa berbekal berpikir kritis dengan kemampuan baik, maka sanggup menemukan solusi permasalahan matematika secara baik pula. Hasil penelitian Ariyanti, Isnaniah dan Jasmienti (2019), telah membuktikan sangat berpengaruhnya daya berpikir kritis terhadap daya tangkap siswa dalam menerima materi sekaligus berpengaruh terhadap penyelesaian akhir dari setiap permasalahan matematika.

Didasarkan dalam penelitian Asih, Irawan, dan Sa'dijah (2017), siswa berpikir kritis dan kreatif matematis dengan kemampuan lemah, salah satu diantaranya bersumber dari proses pembelajaran yang dilangsungkan. Semestinya proses pembelajaran yang dilangsungkan, mengedepankan siswa yang terlibat secara aktif serta adanya kesempatan siswa guna meningkatkan berpikir kritis dan kreatif dari segi kemampuannya. Keadaan ideal ini diungkapkan oleh Johnson (dalam Happy dan Widjajanti, 2014), apabila kebiasaan untuk melatih kemampuan berpikirnya, siswa diberi peluang memperoleh keluasan waktu yang baik, dalam hal mengidentifikasi konsep dan bukan konsep, hipotesis dan kejadian, berita faktual dan pendapat, serta pengetahuan dan keyakinan nantinya dapat terbentuk dengan sendirinya dalam diri siswa. Terbentuk alamiah dalam diri siswa, bukti logis dan terpercaya sebagai pondasi argumen mereka.

Observasi awal yang telah dilakukan sebagai indikasi awal permasalahan penelitian. Fakta sesungguhnya yang terjadi di lapangan, ditemukan pada waktu PPL di kelas X SMAN 115 Jakarta di Tahun Ajaran 2018-2019, memperlihatkan bahwa proses pembelajaran di dalam kelas yaitu guru hanya menjadi titik pusat informasi dan siswa sebatas menunggu penyebaran informasi tersebut. Kondisi pembelajaran menjadi kurang berinteraksinya antara guru kepada siswa, maupun siswa dengan siswa. Sebagian besar siswa belum mampu menemukan solusi secara utuh terhadap permasalahan matematika baik yang ada di buku ataupun yang diberikan guru. Secara kuantitatif, soal yang diselesaikan banyak, namun pemahaman terkait masalah yang ditanyakan masih kurang. Kondisi ini 
merupakan gambaran faktual, kemampuan berpikir kritis siswa dalam pembelajaran matematika masih rendah. Jawaban akhir lebih dipentingkan oleh siswa, angka akhir dari hasil perhitungan itulah yang dianggap sebagai solusi permasalahan. Hal itu menampakkan belum berkembang dengan baiknya kemampuan bernalar siswa.

Kemampuan bernalar menjadi satu kesatuan dari kemampuan berpikir kritis. Pemikir kritis lebih mengetengahkan penyelesaian dari persoalan matematika yang diberikan dan gagasan yang diutarakan memiliki dasar yang tepat, kuat secara rasional, dan cermat. Orang yang gemar mengadu gagasan terhadap asumsi kebenaran atau suatu anggapan yang keliru malahan bukan menjadi gambaran pemikir kritis. Hal ini diperkuat oleh gagasannya Ennis (dalam Zubaidah, 2015: 160), berpikir logis (masuk akal) menjadi akar berpikir kritis dengan berfokus pada penemuan solusi dengan tepat, menjadi keputusan akhir yang dipercaya dan dibuat seseorang pemikir kritis.

Proses pembelajaran matematika ikut andil untuk mengonstruksikan dan menumbuhkan keterampilan dalam kemampuan berpikir nalar, logis, sistematis dan kritis. Panduan dari Depdiknas (dalam Effendi, 2012) mengandung inti, kepada segenap siswa berawal dari jenjang pendidikan dasar perlu diajarkan konsep terkait erat matematika karena dapat memberikan dasar pada siswa dalam hal daya nalar logis, nalar yang analitis, nalar yang sistematis, nalar yang kritis, dan memunculkan nalar kreatif, serta kemampuan saling membantu. Fokus terhadap pengembangan kemampuan berfikir kritis sampai saat ini masih relatif kurang, sehingga masih sangat besar kesempatan untuk mengeksplorasi kemampuan berfikir kritis serta pengembangannya. Pernyataan tersebut semakin menguatkan pentingnya berpikir kritis dalam pembelajaran, khususnya matematika. Kemampuan berpikir kritis perlu dikembangkan agar dapat memecahkan masalah, dan membuat kesimpulan dari berbagai kemungkinan secara efektif. Hal tersebut didasarkan pada hasil penelitian Bridget (2009).

Hasil pengamatan lanjutan, menunjukan bahwa dalam proses pembelajaran Matematika di SMAN 115 Jakarta masih terdapat permasalahan yang erat kaitannya dengan kemampuan berpikir kritis. 
Permasalahan tersebut saling berhubungan dari guru, siswa, sumber belajar, alat peraga belajar dan lingkungan. Pola mengajar guru yang kurang tepat memiliki dampak kepada siswa terkait kemampuan berpikir kritis menjadi lemah. Pola guru dalam memberikan penjelasan kurang memunculkan kesempatan yang seluas-luasnya siswa untuk tampil berpikir kritis. Semestinya, guru membuka akses yang baik dalam menyampaikan ilmu kepada siswa dan jangan mengesampingkan respon yang ditunjukkan siswa atas ilmu tersebut. Minat belajar siswa akan meningkat pada saat siswa mudah dalam menerima ilmu sehingga menumbuhkan antusias dalam belajar.

Penerapan model pembelajaran ceramah (teacher-centered) yang diterapkan guru SMAN 115 Jakarta mengakibatkan tidak ada kesempatan siswa untuk aktif. Permasalahan matematika yang dimunculkan guru untuk siswa belum dapat merangsang siswa untuk aktif dan berinisiatif menemukan berbagai cara (berpikir kreatif) serta sistematis. Permasalahan Matematika yang diberikan guru masih terlalu abstrak, berkutat pada rumus dan simbol. Fakta menunjukkan kegiatan pembelajaran di kelas, guru melakukan transfer pengetahuan secara dominan, materi disampaikan di depan kelas berdasarkan metode ceramah sedangkan siswa menerima materi secara pasif. Keaktifan siswa saat proses pembelajaran ini masih belum maksimal, hanya siswa tertentu saja yang aktif bertanya dan mengungkapkan gagasan, sehingga siswa mengalami kendala saat mengupas solusi dari soal. Karena kurangnya kesempatan yang diberikan, menjadikan siswa segan dan takut mengekspresikan kemampuan berpikir kritisnya. Gagasan matematika siswa baik secara lisan maupun tulisan belum tersampaikan dengan baik, akibatnya tidak maksimal dalam menganalisis soal matematika dengan pola pengerjaan yang berbeda.

Masih minimnya daya berpikir kritis siswa dapat tergambar berdasarkan hasil wawancara peneliti dengan guru matematika di SMAN 115 Jakarta. Indikasinya ditandai dengan pemahaman siswa yang masih rendah mengenai konsep matematika. Data faktual menunjukkan, nilai rata-rata siswa yang berada di atas standar yang ditetapkan oleh sekolah masih sedikit. Data persentase nilai matematika siswa SMA Negeri 115 
Jakarta dilihat pada Tabel 1 berdasarkan Kriteria Ketuntasan Minimal (KKM) yaitu 70.

\section{Tabel 1. Persentase Nilai Matematika Siswa}

\begin{tabular}{ccc}
\hline Nilai & Banyaknya Siswa & Persentase (\%) \\
\hline Di bawah KKM & 80 & 40 \\
Sama dengan KKM & 70 & 35 \\
Di atas KKM & 50 & 25 \\
\hline
\end{tabular}

Sumber: Data SMA Negeri 115 Jakarta

Data dalam Tabel 1 menunjukkan hanya 25\% siswa yang berada di atas KKM. Hal ini menguatkan temuan awal berdasarkan observasi dan wawancara dengan guru matematika terkait dengan kemampuan berpikir kritis.

Guru matematika menyampaikan bahwa kemampuan berpikir kritis yang baik, merupakan modal yang sangat penting bagi siswa. Siswa berbekal berpikir kritis secara baik sanggup memunculkan proses pembelajaran di kelas berjalan aktif dan daya tangkap siswa dalam menerima materi pelajaran menjadi mudah. Rendahnya kemampuan berpikir kritis siswa diakui oleh guru, salah satu penyebabnya adalah proses pembelajaran masih menjadikan guru sebagai pusat pembelajaran, artinya pembelajaran masih bersifat konvensional.

Pembelajaran Realistic Mathematics Education (RME) dengan strategi Means Ends Analysis (MEA) menjadi alternatif guru dalam menunjang kegiatan belajar mengajar. RME merupakan pembelajaran yang mengedepankan proses pemodelan matematika dengan kondisi lingkungan siswa sebagai dasar pembelajaran. Senada dengan pendapat Wijaya (dalam Latipah dan Apriansyah, 2018), menyatakan RME merupakan pendekatan dalam pembelajaran matematika yang menggunakan permasalahan dalam kehidupan nyata yang dialami siswa.

RME yang diadopsi di Indonesia sebagai PMRI (Pendekatan Pendidikan Matematika Realistik Indonesia), merupakan pendekatan yang mampu mendukung siswa untuk mengembangkan proses berpikir dalam menemukan konsep (Mulyatna, 2019). Proses berpikir inilah yang menumbuhkembangkan peningkatan berpikir secara kritis. 
Pembelajaran dengan pendekatan RME ini disinergikan melalui strategi pembelajaran MEA (Means Ends Analysis). Ormrod (2009: 409) mengulas Means-Ends Analysis (MEA) sebagai suatu proses atau cara dalam menyelesaikan suatu masalah yang kemudian membagi menjadi dua atau lebih sub-tujuan dengan dikerjakan pada setiap sub-tujuan secara bertahap. Pembelajaran dengan pendekatan RME ini diharapkan dapat lebih menunjang pembelajaran yang terjadi di dalam kelas jika dikolaborasikan dengan strategi pembelajaran MEA. Kolaborasi pembelajaran melalui pendekatan RME dengan strategi pembelajaran MEA diharapkan memberi kesempatan siswa meningkatkan kemampuan berpikir kritis dalam menguraikan persoalan atau soal yang dimunculkan oleh guru. Siswa dapat mudah mengawali konstruksi nalarnya, dikarenakan menerima pembelajaran didasarkan pada fakta keseharian sehingga persoalan faktual atau biasa ditemui dapat dibayangkan dengan baik oleh siswa, menjadi sesuatu yang tidak abstrak lagi.

Strategi pembelajaran yang tepat, merangsang siswa untuk menumbuhkankembangkan pengetahuan. Tidak hanya itu, kemampuan menganalisis pola-pola pengerjaan yang tepat dalam menggali solusi dari permasalahan yang dihadapi pun menjadi meningkat. Penggunaan strategi yang tepat dan efektif merupakan solusi untuk memaksimalkan proses dan hasil belajar siswa didasari kemampuan berpikir kritis. Siswa diberikan kesempatan mengekspresikan kemampuan dalam pembelajaran, di sisi lain peran guru sebatas fasilitator yang mengarahkan dan memotivasi siswa mengembangkan kemampuan berpikir kritisnya. Semua yang telah diuraikan, merupakan permasalahan serta dasar dari penelitian tentang "Penerapan Pembelajaran Realistic Mathematics Education dengan Strategi Means Ends Analysis untuk Meningkatkan Kemampuan Berpikir Siswa" pada Materi Perbandingan Trigonometri di Kelas X IPS3 SMAN 115 Jakarta.

\section{METODE PENELITIAN}

Penelitian untuk meningkatkan kemampuan berpikir kritis, merupakan tindakan kelas yang dilaksanakan pada siswa kelas X IPS-3 SMAN 115 Jakarta Tahun Pelajaran 2018/2019 dengan pembelajaran 
menggunakan model pembelajaran RME dengan strategi MEA. Mengacu pada Arikunto (2017) penelitian ini dilaksanakan berdasarkan siklus, dengan tahapan setiap siklusnya: diawali rencana (planning), adanya tindakan (action), tindakan disertai pengamatan (observation), dan adanya umpan balik penilaian diri (reflection). Adapun dalam penelitian ini berlangsung 2 siklus. Instrumen dan dokumen pendukung yang digunakan meliputi Rencana Pelaksanaan Pembelajaran, LKS, dan kuis, serta lembar catatan lapangan, lembar observasi pelaksanaan pembelajaran dan seperangkat tes berbentuk uraian. Indikator keberhasilan yaitu skor kemampuan berpikir kritis berada di kualifikasi baik dan keterlaksanaan pembelajaran yang baik menjadi acuan untuk menghentikan siklus.

\section{HASIL PENELITIAN DAN PEMBAHASAN}

Empat fase pada tiap siklus dalam penelitian tindakan kelas yang telah dilaksanakan meliputi, yaitu: diawali rencana, adanya tindakan kelas, pengamatan, dan refleksi terhadap 3 fase di awal. Peneliti pada fase awal telah menyusun perencanaan rencana (yang tertuang dalam Rencana Pelaksanaan Pembelajaran/RPP), Lembar Kegiatan Siswa (LKS), dan soal yang disajikan dalam kuis, serta instrumen lain yang telah dikembangkan, serta digunakan dalam penelitian terdiri dari lembar observasi pelaksanaan pembelajaran dan seperangkat tes penunjang. Proses pembelajarannya sendiri merupakan penerapan dari pembelajaran RME dengan strategi MEA sebagai tindakan kelasnya. Inilah yang menjadikan penelitian ini berbeda. Pembelajaran RME dan strategi MEA dalam penelitian-penelitian sebelumnya (Fauzan and Yerizon, 2013; Asih, Irawan dan Sa'dijah, 2017; Ariyanti, Isnaniah dan Jasmienti, 2019) dilaksanakan secara sendiri-sendiri dan sudah terbukti berdampak baik dalam mengembangkan berpikir kritis siswa. Dengan bukti hasil penelitian yang ada, fokus kajian ini merupakan sinergi antara pembelajaran RME dan strategi MEA

Pengambilan data dengan metode observasi, tertuang dalam lembar observasi memberikan hasil pada pertemuan 1, berdasarkan indikator keterlaksanaan pembelajaran, guru telah mencapai persentase $83,3 \%$. Sedangkan pada indikator lain, hasil pengamatan menunjukkan belum 
dipenuhi, seperti dalam hal: siswa aktif mencari sumber informasi lain baik buku matematika paket atau buku matematika lain, dalam inisiatif menyelesaikan masalah pada LKS dan belum terlaksananya penilaian ataupun apresiasi atas keterampilan dan usaha siswa menemukan solusi, penilaian ataupun apresiasi terhadap keaktifan siswa selama pembelajaran serta belum diakhiri dengan kuis.

Saat pertemuan ke-2, pengambilan data dengan metode observasi, tertuang dalam lembar observasi memberikan hasil adanya peningkatan, berdasarkan indikator keterlaksanaan pembelajaran, guru telah mencapai persentase $88,8 \%$ (meningkat 5,5\% dari pertemuan 1). Sedangkan pada indikator lain, hasil pengamatan menunjukkan masih belum dipenuhi. Indikator sekaligus sebagai komponen RME dengan strategi MEA yang belum dipenuhi, pada saat ada kelompok yang mempresentasikan hasil diskusi yang mengacu pada LKS, kelompok lain belum ada yang memberikan tanggapan ataupun pertanyaan. Padahal siswa sudah diberikan kesempatan untuk "berpikir sejenak", berpikir tentang pengetahuan baru yang telah mereka dapatkan, serta berpikir tentang kekurangan dan kelebihan dalam proses pembentukan pengetahuan baru tersebut. Penyebab belum terlaksananya indikator tersebut, kelompok lain belum merampungkan diskusi topik yang diberikan di LKS, masih segan dan takut menyampaikan gagasan (belum terbiasa). Sebagai alternatif solusi, guru memberikan kelonggaran waktu, sehingga diskusi bisa diselesaikan dan menjadi bahan presentasi pada pertemuan selanjutnya.

Sehingga pada pertemuan ke-3 pada saat ada kelompok yang presentasi berdasarkan LKS, kelompok lainnya memberikan tanggapan dan pertanyaan terlaksana dengan baik. Tercipta suasana kelas yang aktif. Walaupun kesempatan kelompok yang maju presentasi, hanya 1 kelompok saja, mengingat keterbatasan alokasi jam pelajaran. Namun demikian, indikator pada lembar observasi beberapa kelompok diberi kesempatan untuk mempresentasikan LKS (nomor 15) terlaksana dengan baik. 
Tes yang dikerjakan di ujung fase siklus I memberikan hasil persentase skor kemampuan rata-rata berpikir kritis siswa baru sampai $56 \%$, sehingga masih berada dalam kualifikasi kurang. Banyaknya siswa pada tiap tingkatan kualifikasi berpikir kritis disajikan dalam Tabel 2.

Tabel 2. Tingkatan Berpikir Kritis Siswa pada Siklus I

\begin{tabular}{ccc}
\hline No & Kualifikasi & Banyak siswa \\
\hline 1 & Sangat baik & 0 \\
2 & Baik & 2 \\
3 & Cukup & 9 \\
4 & Kurang & 13 \\
5 & Kurang sekali & 10 \\
\hline
\end{tabular}

Data menunjukkan, siswa berada pada kualifikasi kurang (13 siswa) merupakan jumlah siswa terbanyak dibandingkan dengan kualifikasi lainnya. Jumlah siswa pada kualifikasi baik, hanya ada 2 siswa. Sedangkan tiap tes pada akhir siklus, memiliki tiga aspek kemampuan berpikir kritis yang menjadi patokan. Data hasil analisis yang dicapai seluruh siswa pada siklus I berdasarkan tiap aspek kemampuan berpikir kritis diperinci dalam Tabel 3.

Tabel 3. Aspek-Aspek Berpikir Kritis yang Dicapai pada Siklus I

\begin{tabular}{ccccccccc}
\hline No & \multirow{2}{*}{ Aspek } & 1 & 2 & 3 & Total & $\begin{array}{c}\text { Total Skor } \\
\text { Maks }\end{array}$ & \multirow{2}{*}{ Kualifikasi } \\
\hline 1 & A & 60 & 68 & 67 & 195 & 204 & 96 & Sangat Baik \\
2 & B & 47 & 85 & 124 & 256 & 544 & 47 & Kurang Sekali \\
3 & C & 21 & 40 & 20 & 81 & 204 & 40 & \\
\hline
\end{tabular}

Jika diinterpretasikan tentang komponen RME dengan strategi MEA, maka siswa yang berada pada kualifikasi sangat baik memiliki persentase sebesar 96\% yaitu yang ditunjukkan pada Aspek A (elementary clarification) dan dapat dilihat dalam aspek memberikan penjelasan dasar. Selanjutnya, siswa yang masih berada dalam kualifikasi kurang sekali (berdasar persentase sebesar 47\%) yaitu dalam hal menentukan dasar pengambilan keputusan yang ditunjukkan pada aspek $\mathrm{B}$ (the basis for the decision). Begitu juga dalam hal menarik simpulan, siswa juga berada pada kualifikasi kurang sekali (persentase sebesar 40\%) yang ditunjukkan pada aspek C (inference). 
Persentase keterlaksanaan pembelajaran mencapai lebih dari $80 \%$, hasil ini berdasarkan analisis pada siklus I. Dari segi keterlaksanaan pembelajaran sebenarnya telah tercapai, dengan mengacu pada indikator keberhasilan yang ditetapkan. Tetapi, kemampuan berpikir kritis siswa masih berada dalam kualifikasi kurang, ditunjukkan dengan persentase rata-rata skor siswa mencapai 56\% berdasarkan hasil tes. Secara individu, siswa yang telah memenuhi kualifikasi baik, baru ada 2 siswa.

Kalau tinjauannya dalam aspek-aspek berpikir kritis, analisis memberikan hasil, sama-sama pada kualifikasi kurang sekali, pada Aspek B dan C, yaitu tentang kemampuan siswa untuk menentukan dasar pengambilan keputusan (the basis for the decision) dan kemampuan siswa menarik kesimpulan (inference). Tinjauan atas analisis pada siklus I ini kemudian dituangkan dalam refleksi. Refleksi siklus I memberikan keputusan untuk melanjutkan dan melakukan pembelajaran pada siklus II tetap dengan penerapan pembelajaran dengan pendekatan RME disertai strategi MEA, tentunya dengan perbaikan yang mengacu pada analisis data siklus I. Perbaikan yang dimaksud diantaranya terkait pemanfaatan alokasi jam pelajaran dengan membagi alokasi waktu seefisien mungkin. Guru dalam proses pembelajaran, disertai arahan sambil adanya dorongan terhadap siswa ketika dalam berinteraksi berbantuan LKS. Perbaikan selanjutnya, ada penambahan petunjuk dan masukan pada lembar jawab tes akhir siklus yang dibuat peneliti. Hal ini dapat memudahkan siswa dalam menjawab tes akhir siklus II.

Observasi pelaksanaan pembelajaran kemudian dilanjutkan untuk siklus II. Tindakan kelas melalui proses pengajaran oleh guru keterlaksanaannya mencapai $83,3 \%$, data ini diambil mengacu catatan observasi proses pembelajaran pertemuan 1, siklus II. Data lain hasil pengamatan terkait karakter/indikator yang belum dipenuhi berdasar komponen RME dengan strategi MEA, yaitu dalam hal: siswa mengidentifikasi pemodelan masalah kontekstual topik perbandingan trigonometri yang kerja sama sesama siswa tetapi berbeda kelompok, siswa melakukan inisiatif mencari sumber infromasi dari buku pelajaran matematika sebagai upaya untuk membantu menyelesaikan masalah yang disajikan dalam LKS, siswa bekerja mencermati persoalan yang diberikan 
guru di LKS lantas mengidentifikasi, mencatat atau merancang penyelesaian masalah (melakukan pemodelan matematika) merujuk pada LKS.

Sedangkan pertemuan ke-2 pada siklus II, kolaborasi pembelajaran RME dengan strategi MEA disebabkan alokasi yang ada hanya 1 jam pelajaran, sebagian alokasi telah digunakan untuk membahas tugas pada pertemuan sebelumnya sehingga tidak berjalan secara maksimal walaupun sudah sesuai dengan RPP dan indikator keterlaksanaan pembelajarannya terpenuhi.

Siklus II memberikan hasil tes akhir termasuk kualifikasi baik (tercapai 84\%), didapat dari persentase rata-rata skor kemampuan berpikir kritis siswa. Secara rinci, Banyaknya siswa pada tiap kualifikasi disajikan dalam Tabel 4.

Tabel 4. Tingkatan Berpikir Kritis Siswa pada Siklus II

\begin{tabular}{ccc}
\hline No & Kualifikasi & Banyak siswa \\
\hline 1 & Sangat baik & 12 \\
2 & Baik & 19 \\
3 & Cukup & 3 \\
4 & Kurang & 0 \\
5 & Kurang sekali & 0 \\
\hline
\end{tabular}

Tabel 4. memberikan data, siswa dengan kualifikasi baik, memberikan data tertinggi dari segi banyaknya siswa, yaitu 19 siswa. Diikuti kualifikasi tingkatan di atasnya, yaitu sangat baik, dengan banyaknya siswa yang berada pada kualifikasi tersebut 12 siswa. Sedangkan kualifikasi pada tingkatan cukup hanya ada 3 siswa, selebihnya tidak ada yang berada pada kualifikasi pada tingkatan kurang dan kurang sekali.

Kemampuan berpikir kritis yang dilakukan pada setiap akhir (siklus II) terdiri dari 3 aspek yaitu:

Tabel 5. Aspek-Aspek Berpikir Kritis yang Dicapai pada Siklus I

\begin{tabular}{|c|c|c|c|c|c|c|c|c|}
\hline \multirow{2}{*}{ No. } & \multirow{2}{*}{ Aspek } & \multicolumn{3}{|c|}{ No. Butir } & \multirow[b]{2}{*}{ Total } & \multirow{2}{*}{$\begin{array}{c}\text { Total Skor } \\
\text { Maks. }\end{array}$} & \multirow[b]{2}{*}{$\%$} & \multirow{2}{*}{ Kualifikasi } \\
\hline & & 1 & 2 & 3 & & & & \\
\hline 1 & A & 67 & 60 & 68 & & 204 & 96 & Sangat Baik \\
\hline 2 & B & 212 & 226 & 246 & 68 & 816 & 84 & Baik \\
\hline 3 & $\mathrm{C}$ & 53 & 58 & 44 & 155 & 204 & 76 & Baik \\
\hline
\end{tabular}


Dapat diinterpretasikan tentang komponen RME dengan strategi MEA mengacu pada data dalam Tabel 5., kualifikasi sangat baik telah ditunjukkan siswa dengan perolehan persentase sebesar 96\%. Dalam Tabel 5. ditunjukkan dari baris Aspek A (elementary clarification). Hal ini jika yang dilihat adalah aspek memberikan penjelasan dasar. Kemudian siswa masih berada dalam kualifikasi yang sama yaitu kualifikasi baik, pada aspek B dan C. Pada aspek B, the basis for the decision (menentukan dasar pengambilan keputusan), kualifikasi baik (perolehannya 84\%). Sedangkan pada aspek $\mathrm{C}$, inference (menarik kesimpulan, C), siswa juga dalam kualifikasi baik (perolehannya 76\%).

Persentase keterlaksanaan pembelajaran mencapai lebih dari $80 \%$, hasil ini berdasar analisis pada siklus II (berdasar lembar observasi). Dari segi keterlaksanaan pembelajaran sebenarnya telah tercapai, dengan mengacu pada indikator keberhasilan yang ditetapkan. Dari tinjauan yang lain, capaian $84 \%$ pada persentase rata-rata skor kemampuan berpikir kritis siswa (berdasar data hasil tes), termasuk kualifikasi baik. Kualifikasi baik dari segi banyaknya siswa, sudah tercapai 19 siswa.

Dengan demikian, jika melihat analisis data siklus II yang dihasilkan, persentase rata-rata skor kemampuan berpikir kritis siswa telah terjadi peningkatan dengan adanya penerapan pembelajaran dengan pendekatan RME melalui strategi MEA pada siklus II dibandingkan hasil yang diperoleh pada siklus I. Bukan hanya itu, dari segi kuantitas perolehan skor kemampuan berpikir kritis dalam kualifikasi baik jelas mengalami peningkatan banyaknya siswa, dibandingkan pada siklus I. Kolaborasi pembelajaran RME melalui strategi MEA pada siklus II telah berhasil tercapai indikator yang telah ditetapkan, yaitu bila sudah memperoleh skor di atas $75 \%$ sehingga penelitian berakhir sampai pada siklus II.

Data hasil tes pada setiap siklus I dan II pada fase akhir, membuktikan persentase rata-rata skor kemampuan berpikir kritis yang diperoleh siswa meningkat dengan adanya penerapan kolaborasi model pembelajaran RME melalui strategi MEA berdasar siklus I dan siklus II. Lebih jelasnya terkait peningkatan tersebut, rinciannya disajikan dalam diagram pada Gambar 1. 


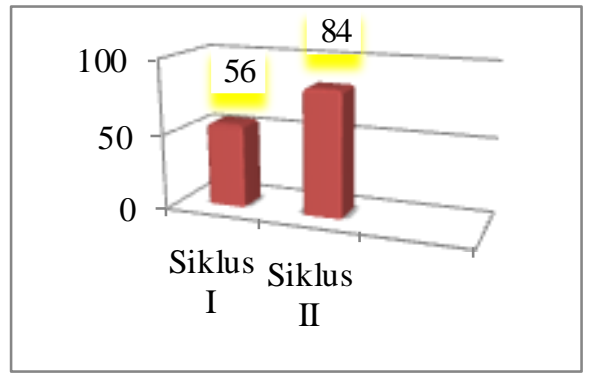

\section{Gambar 1 Kemampuan Berpikir Kritis Mengalami Kenaikan}

Tiap-tiap aspek kemampuan berpikir kritis siswa, persentasenya juga meningkat. Kecuali, siswa pada tahapan memberikan penjelasan dasar (elementary clarification aspect) tidak mengalami peningkatan namun kualifikasinya sudah menempati tingkatan tertinggi (sangat baik). Hal ini menunjukkan, siswa sudah fokus dalam mengidentifikasi permasalahan dalam menyelesaikan soal matematika, mengidentifikasi yang diketahui dan mengidentifikasi inti persoalan. Siswa sudah melakukannya, sebagai pengantar siswa dalam memutuskan untuk mencari dan menentukan strategi atau prosedur yang tepat atau sesuai.

Gambar 2 menunjukkan dokumentasi jawaban siswa pada aspek memberi penjelasan dasar (elementary clarification).

b. Hitunglah jarak kedua kapal tersebut!

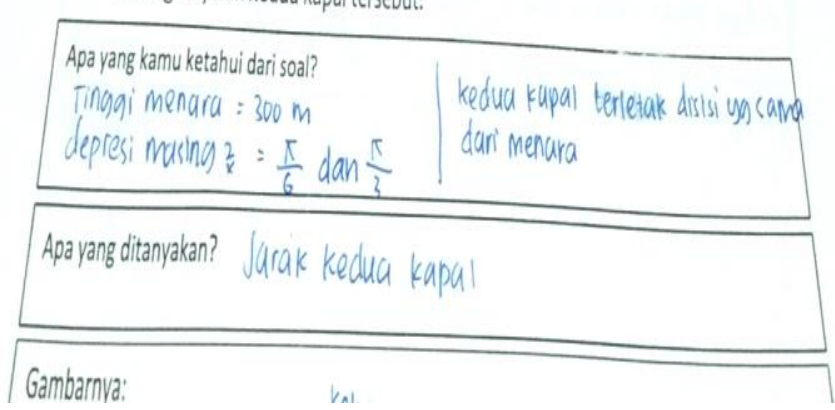

\section{Gambar 2 Dokumentasi yang Menunjukkan Aspek Siswa Memberikan Penjelasan Dasar (Elementary Clarification)}

Peningkatan kualifikasi yang tadinya kurang sekali ke baik (siklus I ke siklus II) dialami siswa pada aspek menentukan dasar pengambilan keputusan (the basis for the decision). Pengambilan keputusan yang dimaksud adalah siswa dalam menemukan solusi permasalahan, 
kemudian membuat suatu keputusan, sudah melalui tahapan dengan disertai alasan kuat (reason) yang logis mendasari suatu langkah ditempuh ke langkah berikutnya.

Gambar 3 terkait dokumentasi yang menunjukkan alasan siswa dalam mengambil keputusan.

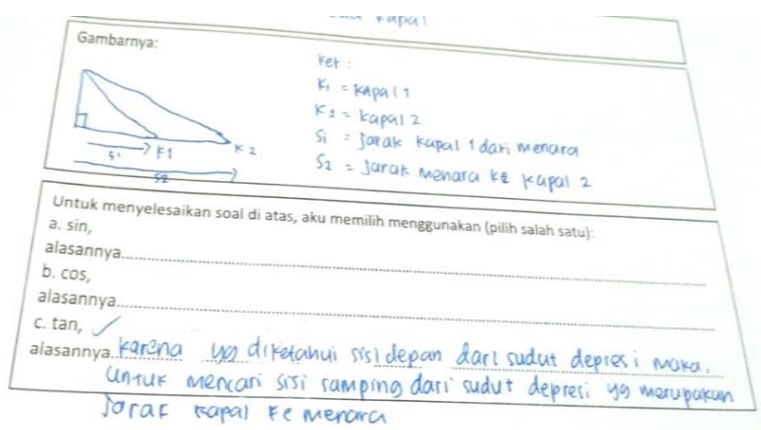

\section{Gambar 3 Dokumentasi Terkait Alasan Siswa dalam Mengambil Keputusan}

Aspek menarik kesimpulan (inference) yang tadinya (siklus I) berada pada kualifikasi kurang sekali, meningkat ke kualifikasi baik (siklus II). Proses siklus I yang dilalui siswa, terdeteksi siswa belum terbiasa menyimpulkan pekerjaan yang siswa uraikan sendiri dalam penyelesaian masalah. Hal tersebut mengacu pada hasil penilaian dan analisis peneliti yang diambil dari simpulan siswa pada akhir siklus I. Hasilnya menunjukkan, siswa sudah yakin pada tahap akhir dari pengerjaan soal, padahal belum sampai pada simpulan akhir, dengan kata lain tanpa menuliskan simpulan akhir jawaban.

Pada siklus II, siswa mendapat arahan dan masukan sehingga jawaban siswa sudah pada tahan penyimpulan akhir. Berdasarkan arahan tersebut, siswa sudah mengerti terkait memperoleh simpulan yang benar semestinya didasarkan atas langkah-langkah yang memuat alasan-alasan masuk akal (logis).

Refleksi siklus I, memunculkan perubahan juga pada lembar jawab tes akhir siklus II dan perubahan dengan modifikasi pada lembar jawab, ikut andil dalam peningkatan kemampuan berpikir kritis dari ketiga aspek. Modifikasi lembar jawaban, menjadikan siswa lebih gampang memaknai tes untuk memikirkan jawaban, sesuai dengan kemampuan 
berpikir kritis yang diperoleh selama penerapan RME dengan strategi MEA.

Siklus II ini, permasalahan kontekstual yang diangkat hanya melibatkan sudut-sudut istimewa saja. Hal ini dimaksudkan siswa bisa memahami konsep dengan benar, bukan malah terjebak dalam kesulitan perhitungan karena siswa tanpa dibekali kalkulator merasa kesulitan operasi hitung seperti yang terjadi pada tes akhir siklus I. Gambar 4 menunjukkan diagram balok peningkatan setiap aspek kemampuan berpikir kritis siswa (dalam \%), seperti yang diuraikan sebelumnya, pada aspek A tidak ada peningkatan, pada aspek $\mathrm{B}$ dan $\mathrm{C}$ yang mengalami peningkatan.

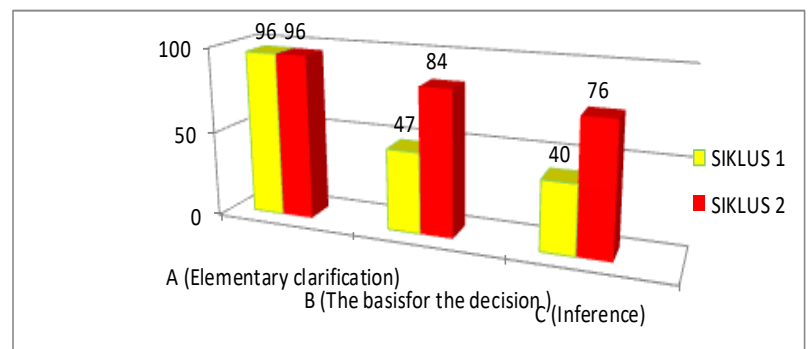

\section{Gambar 4 Digram Analisis Persentase Setiap Aspek pada Kemampuan Berpikir Kritis}

\section{Keterangan:}

Aspek yang diamati, A pada tahapan memberikan penjelasan dasar, B pada tahapan menentukan dasar pengambilan keputusan, $\mathrm{C}$ pada tahapan menarik kesimpulan.

Gambar 4 merupakan diagram yang menyajikan data, aspek yang dominan naiknya (yaitu sebesar 28\%) adalah aspek $\mathrm{B}$ the basis for the decision (menentukan dasar pengambilan keputusan). Sedangkan aspek A elementary clarification (memberikan penjelasan dasar) tidak mengalami peningkatan. Hal tersebut bisa diterima, karena aspek A sudah berada pada tingkatan tertinggi, yaitu sangat baik. Sedangkan diagram secara keseluruhan terkait perbaikan kemampuan berpikir kritis siswa disajikan pada Gambar 5. 

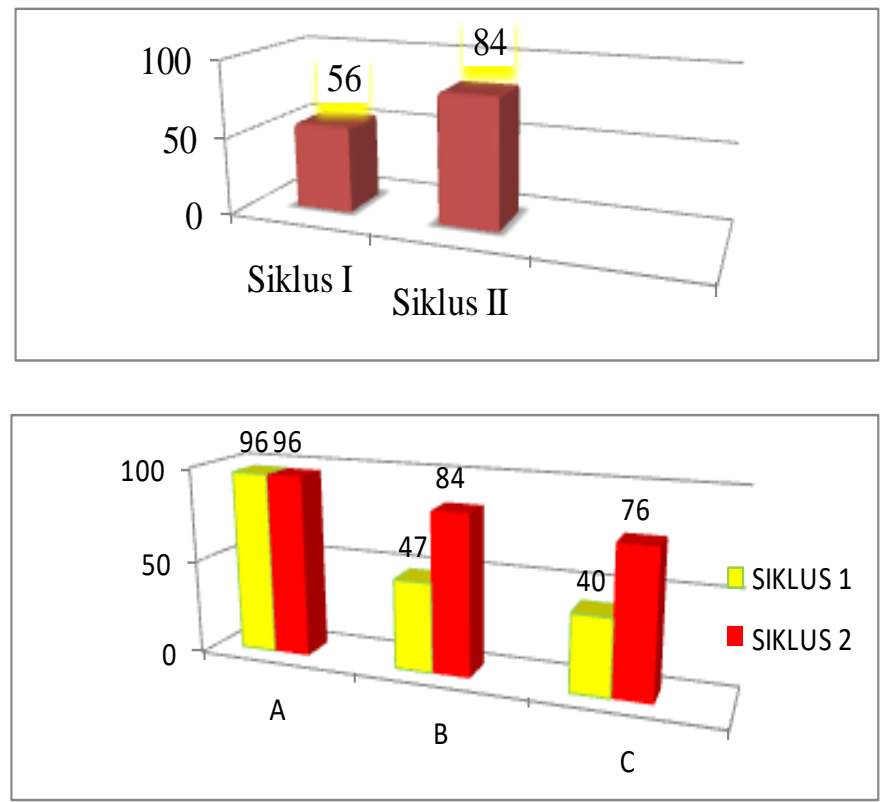

\section{Gambar 5 Diagram Perbaikan Kemampuan Berpikir Kritis Siswa Secara Keseluruhan}

Dari siklus I ke siklus II, skor yang diperoleh atas kemampuan berpikir kritis dalam kualifikasi baik mengalami peningkatan, yaitu dari 2 siswa menjadi 19 siswa, dapat dilihat dari analisis hasil tes akhir pada setiap siklusnya. Tabel 6. memperlihatkan data rinci banyaknya siswa pada tiap-tiap kualifikasi kemampuan berpikir kritis tiap siklus.

Tabel 6. Persebaran Tingkatan Kemampuan Berpikir Kritis Siswa pada Siklus I dan Siklus II

\begin{tabular}{cccc}
\hline \multirow{2}{*}{ No } & \multirow{2}{*}{ Kualifikasi } & \multicolumn{2}{c}{ Banyaknya siswa } \\
& Siklus I & Siklus II \\
\hline 1 & Sangat baik & 0 & 12 \\
2 & Baik & 2 & 19 \\
3 & Cukup & 9 & 3 \\
4 & Kurang & 13 & 0 \\
5 & Kurang sekali & 10 & 0 \\
\hline
\end{tabular}

Segi kognitif siswa meningkat sejalan dengan peningkatan kemampuan berpikir kritis mengindikasikan kemampuan berpikir kritis diperlukan dalam memahami materi pelajaran ataupun untuk menemukan solusi permasalahan matematika. Pemikiran yang hanya didasarkan 
hafalan tidak cukup untuk dapat memahami konsep dan permasalahan matematika, tetapi dibarengi kemampuan berpikir kritis. Melalui suasana belajar yang baru, dengan penerapan model pembelajaran RME dengan strategi MEA, siswa mempunyai ruang dan kesempatan untuk proses identifikasi, analisis serta evaluasi permasalahan matematika yang sesuai kesehariannya dengan cermat dan tepat. Proses yang dilalui siswa, membangun pengetahuan berbantuan LKS, dan menemukan kembali konsep melalui contoh riil, sehingga siswa dapat mengembangkan kemampuan bernalarnya secara kritis dalam menemukan solusi dari masalah yang dihadapi. Hal ini dikuatkan oleh pendapat Fauzan and Yerizon (2013), proses eksplorasi soal-soal dengan tema keseharian siswa, membutuhkan inisiatif untuk memunculkan ide jalan penyelesaian, maka faktor kemandirian belajar juga ikut berperan. Hal ini semakin menegaskan bahwa model pembelajaran RME, dapat menjadi alternatif proses pembelajaran di kelas.

\section{SIMPULAN}

Penerapan pembelajaran RME dengan strategi MEA telah meningkatkan kemampuan berpikir kritis siswa. Dari siklus I ke siklus II menunjukkan, kemampuan berpikir kritis mengalami kenaikan rata-rata skor sebesar $28 \%$. Kenaikan rata-rata skor sebesar $28 \%$ didasarkan hasil analisis tes pada akhir siklus I diperoleh pencapaian 56\% (kualifikasi kurang), kemudian terjadi peningkatan, tes pada akhir siklus II menjadi $84 \%$ (kualifikasi baik). Akibat positif lainnya, siswa terbiasa menerapkan kemampuan berpikir kritis untuk menemukan solusi yang tepat dalam permasalahan matematika. Siswa dengan kualifikasi baik dalam kemampuan berpikir kritis, mengalami peningkatan dari siklus I hanya 2 siswa pada siklus II menjadi 19 siswa.

\section{DAFTAR PUSTAKA}

Arikunto, S. (2017). Penelitian Tindakan Kelas. Jakarta: PT Bumi Aksara

Ariyanti, D., Isnaniah, I., \& Jasmienti, J. (2019). Pengaruh Penerapan Model Pembelajaran Means-Ends Analysis Terhadap Kemampuan 
Berpikir Kritis Matematika Siswa Kelas VIII Smp N 1 Rao Tahun Pelajaran 2018/2019. JURING (Journal for Research in Mathematics Learning), 2(2), 111-117. https://doi.org/10.24014/juring.v2i2.7344

Asih, A. K., Irawan, E. B., \& Sa'dijah, C. (2017). PENERAPAN REALISTIC MATHEMATICS EDUCATION UNTUK MENINGKATKAN KEMAMPUAN BERPIKIR. Jurnal Pendidikan: Teori, Penelitian, Dan Pengembangan, 2(4), 524-530. https://doi.org/http://dx.doi.org/10.17977/jptpp.v2i4.8787.

Retrieved from: https://www.researchgate.net/publication/337025108_Pengaruh_Pe nerapan_Model_Pembelajaran_Means-

Ends_Analysis_Terhadap_Kemampuan_Berpikir_Kritis_Matematik a_Siswa_Kelas_VIII_Smp_N_1_Rao_Tahun_Pelajaran_20182019 Bridget, A. (2009). Encouraging Critical Thinking in Online Threaded Discussions. Journal of Educators Online, 6(1). https://doi.org/10.9743/JEO.2009.1.1. Retrieved from: https://www.researchgate.net/publication/26578826_Encouraging_ Critical_Thinking_in_Online_Threaded_Discussions/citation/downl oad

Effendi, L. A. (2012). Pembelajaran Matematika dengan Metode Penemuan Terbimbing untuk Meningkatkan Kemampuan Representasi dan Pemecahan Masalah Matematis Siswa SMP. Jurnal Penelitian Pendidikan, 13(2), 1-10. Retrieved from http://jurnal.upi.edu/penelitian-

pendidikan/view/1400/pembelajaran-matematika-dengan-metodepenemuan-terbimbing-untuk-meningkatkan-kemampuanrepresentasi-dan-pemecahan-masalah-matematis-siswa-smp.html

Fauzan, A., \& Yerizon. (2013). Pengaruh Pendekatan RME dan Kemandirian Belajar Terhadap Kemamampuan Matematis Siswa. In S. Dwi, H. Apkuanbo, \& S. Saidi (Eds.), Prosiding Semirata FMIPA Universitas Lampung (pp. 7-14). Retrieved from http://jurnal.fmipa.unila.ac.id/semirata/article/view/699/519

Happy, N., \& Widjajanti, D. B. (2014). KEEFEKTIFAN PBL DITINJAU 
DARI KEMAMPUAN BERPIKIR KRITIS DAN KREATIF MATEMATIS, SERTA SELF-ESTEEM SISWA SMP. Jurnal Riset Pendidikan Matematika, 1(1), 48-57. Retrieved from https://journal.uny.ac.id/index.php/jrpm/article/view/2663/2216

Mulyatna, F. (2019). Proses Pembentukan Konsep dalam Menemukan Kembali Teorema Pythagoras dan Miskonsepsi yang Terjadi dengan Pendekatan Pendidikan Matematika Realistik Indonesia (PMRI). ARITHMETIC: Academic Journal of Math, 1(1), 1-22. https://doi.org/http://dx.doi.org/10.29240/ja.v1i1.762. Retrieved from: http://journal.iaincurup.ac.id/index.php/arithmetic/ article/view/762

Ormrod, J. E. (2009). Psikologi Pendidikan: Membantu Siswa Tumbuh dan Berkembang (Edisi Keenam). Jakarta: Erlangga

Zubaidah, A. (2015). Psikologi Pembelajaran Matematika. Yogyakarta: Aswaja Pressindo 
34 | Utarni dan Mulyatna: Penerapan Pembelajaran Realistic Mathematics Education ... 